\title{
Development of Embedded System-Based Lens-Less Microscopy System and Testing on Pathological Samples
}

\author{
Muhammed Ali Pala ${ }^{1 *}$, Mustafa Zahid Y1ldız

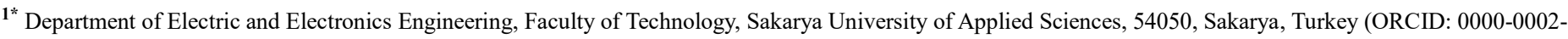 \\ 8153-7971),pala@subu.edu.tr \\ ${ }^{2}$ Department of Electric and Electronics Engineering, Faculty of Technology, Sakarya University of Applied Sciences, 54050, Sakarya, Turkey (ORCID: 0000-0003-
} 1870-288X),mustafayildiz@subu.edu.tr

(1st International Conference on Applied Engineering and Natural Sciences ICAENS 2021, November 1-3, 2021)

(DOI: 10.31590/ejosat.999707)

ATIF/REFERENCE: Pala, M.A, Yıldız, M.Z (2021). Development of Embedded System-Based Lens-less Microscopy System and Testing on Tissue Samples. European Journal of Science and Technology, (28), 357-361.

\begin{abstract}
In this study, a low cost and portable general-purpose lens-less microscopy system suitable for clinical conditions was designed and its performance was increased with the help of image processing algorithms without using numerical approaches. In order to avoid the noises caused by the light source or the imaging sensor, the flat field correction method was applied to the images in real time and then interpolation was applied to the images. The microscopy system is integrated into the embedded system and it is aimed to display in RGB color space. By applying flat field correction and interpolation to the obtained images in real time, the SNR and contrast value of the images were improved. The success of the imaging system was examined with a standard calibration chart. The improvement obtained by calculating the pixel intensity values for pre-processing and post-processing is shown. Various tissue samples were examined with the system and its success on medical samples was demonstrated. It has been shown on tissue samples that the system reaches $2.5 \mu \mathrm{m}$ resolution in imaging tissue samples. It has been shown that the proposed system can be used for imaging pathological tissues in intraoperative procedures and can reduce the examination time. In addition, the obtained system has the potential to be used in the examination of other micro-sized medical samples.
\end{abstract}

Keywords: lens-free microscopy, lab-on-a-chip, medical imaging, digital pathology.

\section{Gömülü Sistem Tabanlı Lenssiz Mikroskopi Sisteminin Geliştirilmesi ve Patolojik Örnekler Üzerinde Test Edilmesi}

$\ddot{O} \mathbf{z}$

Bu çalışmada, klinik şartlar için elverişli, düşük maliyetli ve taşınabilir genel amaçlı bir lenssiz mikroskopi sistemi tasarlanmış ve nümerik yaklaşımlar kullanılmadan görüntü işleme algoritmaları yardımıyla performansı arttırılmış̧ır. Işsk kaynağından veya görüntüleme sensöründen kaynaklı oluşan gürültülerin önüne geçebilmek amacıyla görüntülere gerçek zamanlı olarak homojen alan düzeltmesi metodu uygulanmış ve ardından görüntülere interpolasyon uygulanmıştır. Mikroskopi sistemi gömülü sisteme entegre edilmiş, RGB renk uzayında görüntüleme yapabilmesi amaçlanmıştır. Elde edilen görüntülere gerçek zamanlı olarak homojen alan düzeltmesi ve interpolasyon uygulanarak görüntülerin SNR ve kontrast değeri iyileştirilmiştir. Görüntüleme sisteminin başarısı standart kalibrasyon çubuğu ile incelenmiştir. Ön-işleme öncesi ve sonrası için piksel yeğinlik değerleri hesaplanarak elde edilen iyileştirme miktarı gösterilmiştir. Sistemle muhtelif doku örnekleri incelenerek, medikal örnekler üzerindeki başarısı gösterilmiştir. Sistemin doku örneklerinin görüntülenmesinde $2.5 \mu \mathrm{m}$ çözünürlüğe ulaştığı doku örnekleri üzerinde gösterilmiştir. Amaçlanan sistem, intraoperatif işlemlerde patolojik dokuların görüntülenmesinde kullanılabileceği, inceleme süresini düşürebileceği gösterilmiştir. Ayrıca elde edilen sistem diğer mikro boyutta olan medikal örneklerin incelenmesinde de kullanılabilecek potansiyeldedir.

Anahtar Kelimeler: Lenssiz mikroskopi, Çip-üstü-laboratuvar, Medikal görüntüleme, Dijital patoloji

* Corresponding Author: pala@subu.edu.tr 


\section{Introduction}

The imaging of medical samples is of great importance in the practice and conduct of diagnostic and therapeutic procedures in the clinic. For this purpose, the invention of systems that allow imaging at the micro level has brought revolutions in the medical field (Hooke 1665). Although there are many types of advanced microscopes today, the complexity of optical components, low spatial resolution, small field of view, and difficulty in focusing are among the main problems of optical microscopes (Greenbaum et al. 2012).

Micro-nano-level sensors, which have developed depending on semiconductor technology in recent years, have led to the emergence of systems known as lab-on-a-chip in the healthcare field. It has been successfully demonstrated in many studies that these revolutionary systems in the field of imaging perform micro-level imaging using simple materials (Mudanyali et al. 2009; Seo et al. 2009). Imaging with lens-less microscopy basically consists of the imaging sensor and the light source. The sample to be imaged is placed directly on the imaging sensor, taking into account the imaging principle, and is illuminated by the light source. The light source illuminating the medical samples creates density information with different coefficients on the imaging sensor and these data are recorded by the sensor. Charge-matched semiconductors (CCD) or complementary metal oxide semiconductors (CMOS) can be used as imaging sensors for this purpose (Greenbaum et al. 2012; Yang et al. 2019). However, CMOS sensors are more suitable for this method due to the compatibility in production technologies (Polytechnique and Lausanne 2014).

Lens-less micro-level imaging systems can be grouped under two general headings as contact-mode imaging and digital holographic imaging (Wu and Ozcan 2018). The first group, the contact-mode imaging method, is designed in such a way that the distance between the sample plane and the sensor plane is minimal. In this principle, it is aimed to collect information over the active region of the sensor plane so that the beams passing through the sample plane are exposed to less noise (Ji et al. 2007). In this method, the pixel size of the imaging sensor becomes an important parameter because the size of the pixels in the active region of the imaging sensor is reduced and the number of photons collected increases. The general structure of the lens-less imaging system is shown in Figure 1.

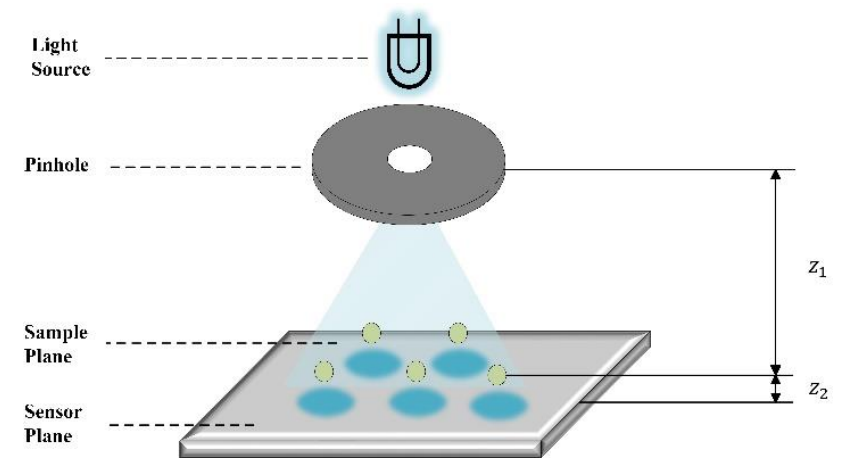

Figure 1. General structure of lens-less microscopy

Examination and analysis of medical images is very important for the execution of clinical processes. Traditional imaging e-ISSN: 2148-2683 methods are difficult to integrate and consist of costly components. In addition, interpretation of the images obtained and obtaining fast results are very important for diagnosis and treatment processes (Boyraz at al. 2019; Çimen et al. 2019; Pala et al. 2019). In this study, a lens-less imaging system that can be used in medical imaging and can operate in real-time embedded system is designed. The contrast value of the images has been increased by applying various pre-processing methods. After all the pre-processing, the resolution value of the system was increased and the results were examined on the calibration chart and various tissue samples.

\section{Material and Method}

In this study, an embedded computer-based lens-less microscopy system that allows real-time imaging of medical samples is designed. In order to improve the SNR and contrast value of the images obtained from the imaging system, real-time flat field correction was applied to the images, and then the spatial resolution of the images was increased by interpolation methods.

\subsection{Lens-less Imaging System Parameters}

SONY IMX219 PQ imaging sensor was used to obtain images of medical samples. The sensor has a square pixel size of $1.12 \mu \mathrm{m}$, the active pixel region has approximately $10 \mathrm{~mm}^{2}$ areas. Therefore, it provides a field of view of $10 \mathrm{~mm}^{2}$ sizes of tissues. This size provides approximately 2 times larger field of view than optical microscopes with 10x lens. The imaging sensor used produces density information at different rates according to the wavelengths of the lights falling on the sensor. The imaging sensor used in the system design gives a maximum intensity response of $95.85 \%$ at $600 \mathrm{~nm}$ red light, $99.26 \%$ at $520 \mathrm{~nm}$ green light, and $80.51 \%$ at $460 \mathrm{~nm}$ blue light. There is a distance of 100 $\mu \mathrm{m}$ between the imaging sensor and the sample plane, and $5 \mathrm{~cm}$ between the sample plane and the pinhole.

While selecting the LED source for the imaging system, the wavelength at which the sensor responds to the maximum was taken into account. A $3 \mathrm{~W}$ LED source with two different peak wavelengths is used in the system. The LED source with wavelengths of $442 \mathrm{~nm}$ and $590 \mathrm{~nm}$ also radiates at the wavelength at which the sensor gives maximum response. In order to keep the LED source stable, a constant current source with $350 \mathrm{~mA}$ output is used. The LED source part is placed $1 \mathrm{~cm}$ away from the pinhole light source with a diameter of $150 \mu \mathrm{m}$ in order to become partially coherent. Therefore, it is aimed to reduce light-induced diffraction in images. The designed imaging system is shown in Figure 2. 


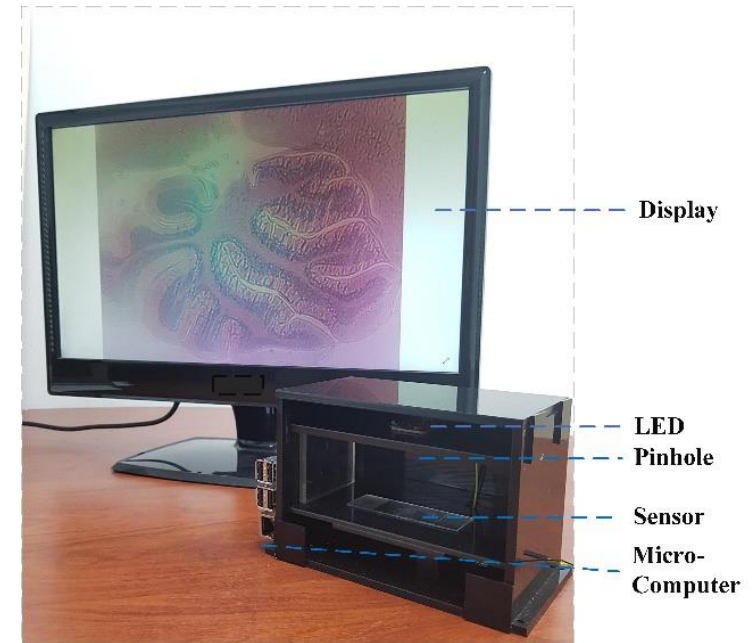

Figure 2. The designed imaging system

\subsection{Image Pre-Processing}

Various distortions and noises occur in the images obtained by the microscopy system due to the light source and the imaging sensor. In addition, speckle noise occurs in images from imaging sensor sources. In order to minimize these effects and to eliminate uneven illumination on the sample, dynamic flat field correction was applied to the images in real time. The flat field correction method is a method designed to eliminate the dark currents and gain sources problems on the images. In the study, images obtained in RGB space were first converted to HSV space, corrected in this space, and then displayed on the output screen by applying cubic interpolation to the images. Mathematical relation of flat field correction is given in Equation 1

$I_{H}(x, y, z)=\frac{\left(I_{R}(x, y, z)-I_{D}(x, y)\right)(M)}{I_{B}(x, y)-I_{D}(x, y)}$

In the equation, $I_{H}(x, y, z)$ is the corrected image, $I_{R}(x, y, z)$ is the raw image, $I_{D}(x, y)$ is the dark image, $M$ is the average pixel value of the corrected flat field image, and $I_{B}(x, y)$ is the bright image.

\subsection{Calibration of the System}

Before the images of the pathological samples were obtained with the produced system, pixel density analyzes were carried out with a linear calibration bar with $5 \mu \mathrm{m}$ spacing. With this method, the ability of the imaging system to distinguish between the background and the object has been demonstrated. Images and density analyzes of the calibration chart are given in Figure 3.

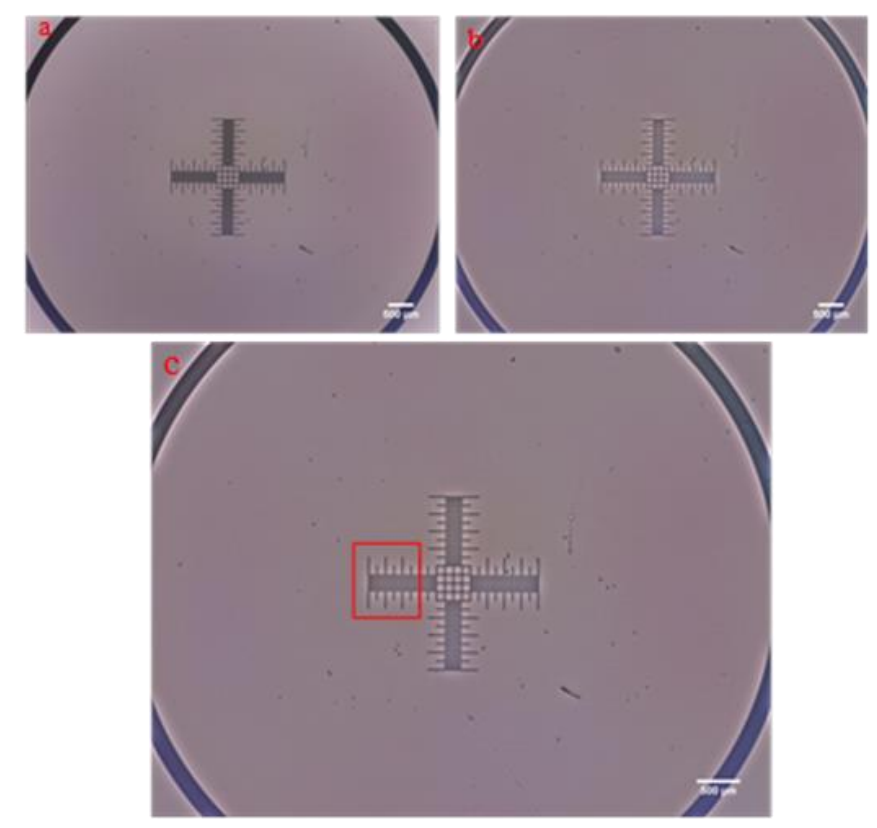

Figure 3 Image obtained with the calibration chart a) Raw image of the chart. b) Image with flat field correction applied. c)

Cubic interpolated image. (Calibration line $500 \mu \mathrm{m}$ )

In Figure 4, the pixel density values of the calibration slide obtained before and after the actual pre-processing steps are given.

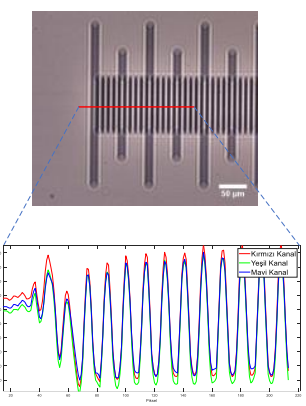

(a)

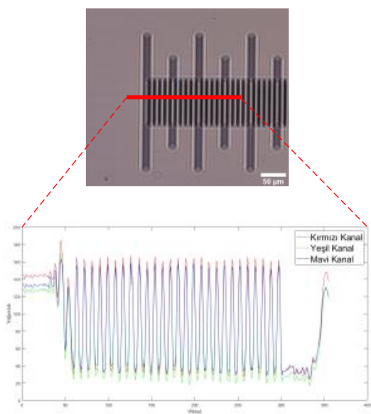

(b)
Figure 4. Selected ROI from Figure 3-(c) and pixel density plots. a) Intensity values before pre-processing, b) Intensity values after pre- processing

The maximum, minimum and difference values of the calibration slide, whose pixel intensity graphs are given in Figure 4 , are given before and after pre-processing of the intensity values in Table 1. As can be seen from the table, the applied methods have increased the selectivity value between the background and the object, and thus the resolution of the imaging system has increased.

Table 1. Pixel intensity data obtained before and after the

\begin{tabular}{cccccc} 
& \multicolumn{4}{c}{ applied processes } \\
\cline { 2 - 5 } & Channel & Max. & Min. & Difference \\
\hline Before & $\mathrm{R}$ & 161 & 34 & 127 \\
Pre- & $\mathrm{B}$ & 154 & 35 & 119 \\
\cline { 2 - 5 } Processing & $\mathrm{G}$ & 158 & 22 & 136 \\
\hline After & $\mathrm{R}$ & 205 & 41 & $\mathbf{1 6 4}$ \\
\cline { 2 - 5 } Pre- & $\mathrm{B}$ & 199 & 48 & $\mathbf{1 5 1}$ \\
Processing & $\mathrm{G}$ & 192 & 33 & $\mathbf{1 5 9}$ \\
\cline { 2 - 5 } & & & &
\end{tabular}




\subsection{Medical Imaging}

Real-time image of various tissue samples stained with haematoxylin-eosin dye is given in Figure 5. The viewing area is approximately $10 \mathrm{~mm}^{2}$. Scale bars representing $200 \mu \mathrm{m}$ size are placed in the lower right part of all images. The selected ROI 1 is given in Figure 5-a and the image of ROI 2 is given in Figure 5b. Nuclei structures are concentrated in the randomly selected region.

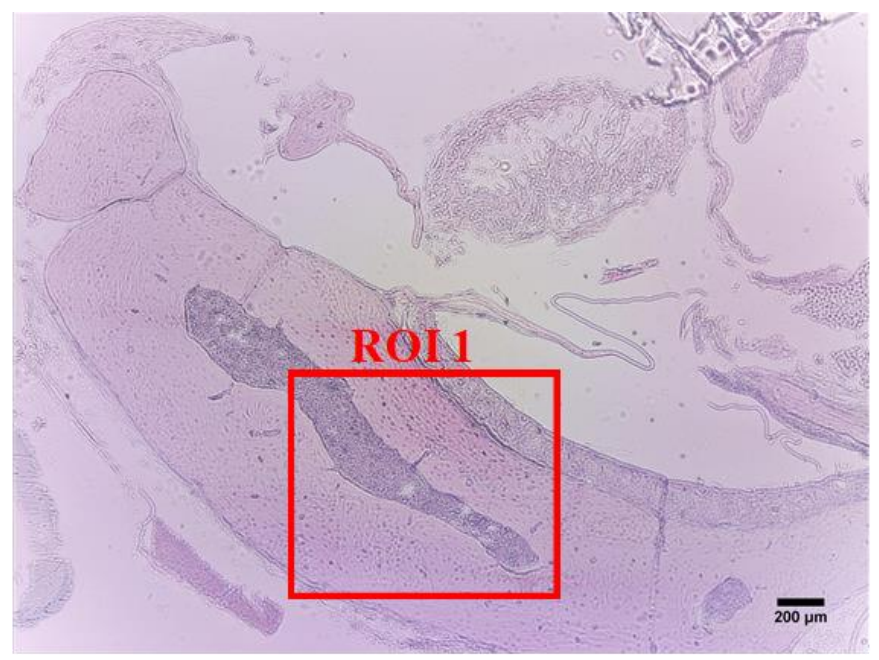

(a)

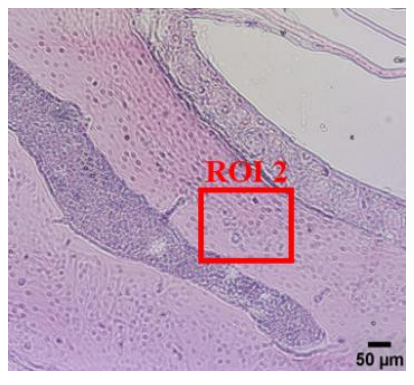

(b)

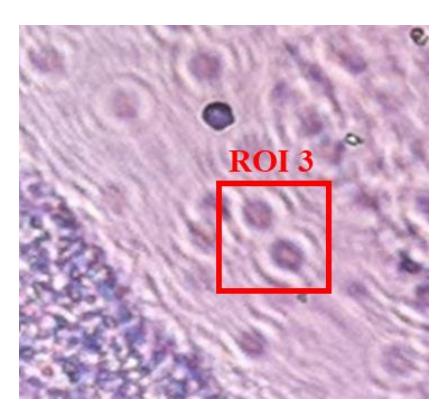

(c)
Figure 5. Image obtained from tissue sample, a) Image of whole slide b) Image of ROI 1, c) Image to ROI 2

The selected ROI 3 image is given in Figure 6. In this region, there are two different core structures with radius sizes of $2.50 \mu \mathrm{m}$ and $2.30 \mu \mathrm{m}$. The distance between the two cores is $2.10 \mu \mathrm{m}$ and all imaging system can be resolved.

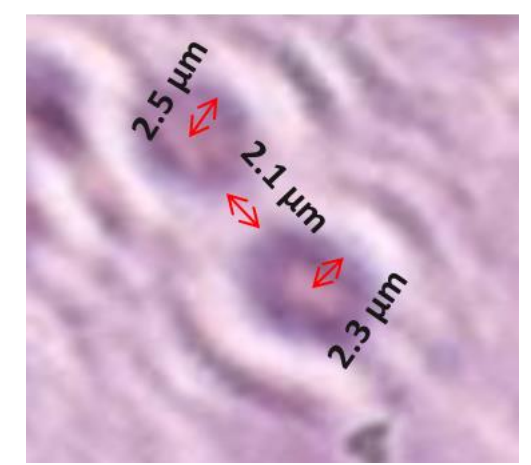

Figure 6. ROI 3 and radius information.

In Figure 7, the linear density graph of the nuclei structures in Figure 6 is given in the green color channel. The centre of two different nuclei can be easily resolved with the help of imaging system.

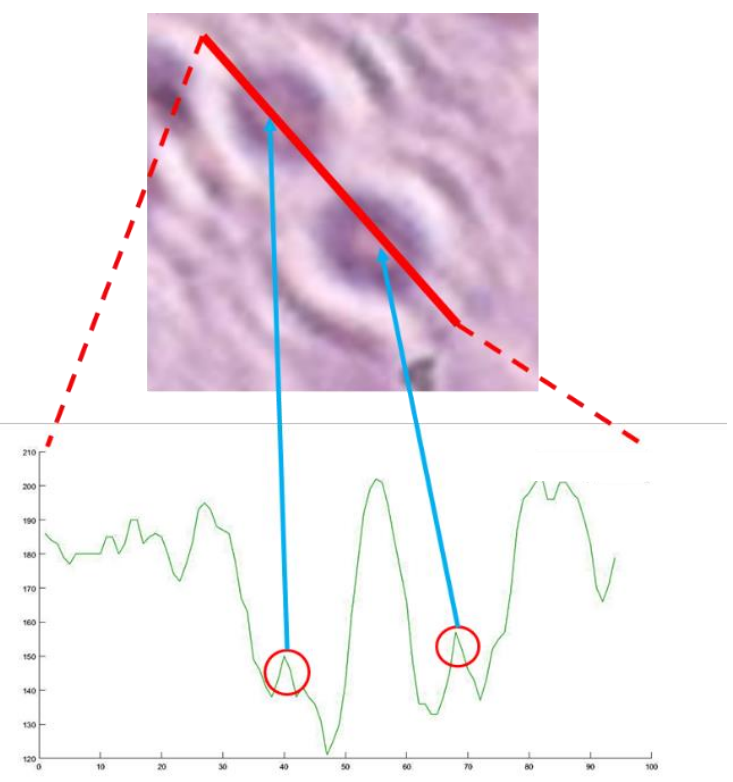

Figure 7. Nuclei structures and linear pixel density plot

\section{CONCLUSION}

Lab-on-a-chip systems are increasing in usage day by day due to the various advantages such as low cost and integration. It is foreseen that these systems will gain more importance and reach a wider usage area in the near future. In this study, it is aimed that all the applied methods can work in an embedded system in real time. The success of the imaging system was demonstrated with a calibration chart and its suitability for medical imaging was demonstrated with tissue samples. Cost, spatial resolution and speed are kept at the optimum level in the produced imaging system. The produced imaging system, with its design and imaging strategies, is capable of providing convenience and a different perspective to clinical studies.

\section{Acknowledge}

This work was supported by Sakarya University of Applied Science Scientific Research Projects Coordination Unit (SUBU BAPK, Project Number: 2020-01-01-011). The author, Muhammed Ali PALA, is grateful to The Scientific and Technological Research Council of Turkey for granting a scholarship (TUBITAK, 2211-C) for him Ph.D. studies.

\section{References}

Boyraz, Ömer Faruk, Muhammed Ali Pala, and Murat Erhan Çimen. 2019. "Mikrobilgisayar Tabanlı El- Bilek Damar Örüntüleri Kullanılarak Biyometrik Kimlik Doğrulama İşleminin Yapılması." Academic Perspective Procedia 2019(November): 593-600.

Çimen, Murat Erhan et al. 2019. "Modelling of Chaotic Motion Video with Artificial Neural Networks." CHAOS TEORY AND APPLICATIONS 1(1): 38-50.

Greenbaum, Alon et al. 2012. "Imaging without Lenses: Achievements and Remaining Challenges of Wide-Field 
on-Chip Microscopy." Nature Methods 9(9): 889-95.

Hooke, Robert. 1665. Micrographia by Robert Hooke, 1665. The British Library.

Ji, Honghao, David Sander, Alfred Haas, and Pamela A. Abshire. 2007. "Contact Imaging: Simulation and Experiment." IEEE Transactions on Circuits and Systems I: Regular Papers 54(8): 1698-1710.

Mudanyali, Onur et al. 2009. "Lensless On-Chip Imaging of Cells Provides a New Tool for High-Throughput Cell-Biology and Medical Diagnostics." Journal of Visualized Experiments.

Pala, Muhammed Ali et al. 2019. "Meme Kanserinin Teşhis Edilmesinde Karar Ağacı Ve KNN Algoritmalarının Karşılaştırmalı Başarım Analizi." Academic Perspective Procedia 2(3): 544-52.

Polytechnique, Cole, and Rale D E Lausanne. 2014. "Design and Implementation of CMOS Image Sensors for Biomedical Applications." 6229.

Seo, Sungkyu et al. 2009. "Lensfree Holographic Imaging for OnChip Cytometry and Diagnostics." Lab on a chip 9(6): $777-$ 87.

Wu, Yichen, and Aydogan Ozcan. 2018. "Lensless Digital Holographic Microscopy and Its Applications in Biomedicine and Environmental Monitoring." Methods 136: 4-16. http://dx.doi.org/10.1016/j.ymeth.2017.08.013 (February 7, 2019).

Yang, Ke et al. 2019. "Recent Development of Portable Imaging Platforms for Cell-Based Assays." Biosensors and Bioelectronics 124-125(October 2018): 150-60. https://doi.org/10.1016/j.bios.2018.10.024. 